\title{
Pertinent changes in adult brain neurobiology due to trauma
}

\author{
Christos Tsopelas \\ From $1^{\text {st }}$ International Congress on Neurobiology and Clinical Psychopharmacology and European \\ Psychiatric Association Conference on Treatment Guidance \\ Thessaloniki, Greece. 19-22 November 2009
}

\section{Introduction}

Contrary to the general feeling of safety and stability in contemporary western societies traumatic events arise by nature unrepentantly due to natural disasters, terrorism or criminal acts. People affected in events alter brain development in early ages and differentiate the structure and function of several areas in the adult brain.

\section{Methods}

We perform thorough research of main medical databases, and web search engines for relevant studies with related key words and scrutinize them, before concluding about appropriateness.

\section{Results}

There are important and complex alterations in neurobiological networks that are responsible of triggering defensive reactions of autonomic, immune and endocrine systems forming different aspects of posttraumatic stress disorder. Brain areas involved are thalamus, amygdala, hippocampus, neocortex, corpus callosum and different neurotransmitter systems are accordingly implicated.

\section{Conclusion}

The symptomatology of mental disorder is the aftermath of the individual trying to face extraordinary events that fundamentally alter the vision and interpretation of its existence in an environment where the unexpected is the rule and not the exception. Traumatic events put our secluded way of living in danger and have as a consequence the development of different neurobiological

Psychiatric Hospital of Attica, Greece

๑ 2009 Tsopelas; licensee BioMed Central Ltd. responses on various brain circuits leading to the appearance and establishment of mental disorders.

Published: 22 April 2010

doi:10.1186/1744-859X-9-S1-S29

Cite this article as: Tsopelas: Pertinent changes in adult brain neurobiology due to trauma. Annals of General Psychiatry 2010 9(Suppl 1): S29.

Submit your next manuscript to BioMed Central and take full advantage of:

- Convenient online submission

- Thorough peer review

- No space constraints or color figure charges

- Immediate publication on acceptance

- Inclusion in PubMed, CAS, Scopus and Google Scholar

- Research which is freely available for redistribution

Submit your manuscript at www.biomedcentral.com/submit 